\title{
Modelli dinamici interattivi per il patrimonio costruito
}

\author{
Fabrizio Banfi
}

Abstract

Negli ultimi anni metodi innovativi in gradi di migliorare il processo di digitalizzazione degli edifici storici basati su un proceso scan-to-BIM, ha portato innumervoli benefici in differenti campi disciplinari orientati alla gestione del patrimo costruito. On the other hand, il processo scan-to-BIM ancora oggi prevede forme statice e bassi livelli di interattivita'tra utente e modelli digitali. Per questo motivo, la ricerca dell'autore negli ultimi anni si e' focalizzata nell'aumentare i paradigmi dell'utilita' e interattivita'dei modelli digitali con lo scopo di migliorare la trasmissibilita' dei valori tangibili e intagibili del nostro patrimonio costruito con I implementazione di strumenti e tecniche di ultima generazione nel campo dell'HBIM, Digital Twin ed Extended Reality (XR).
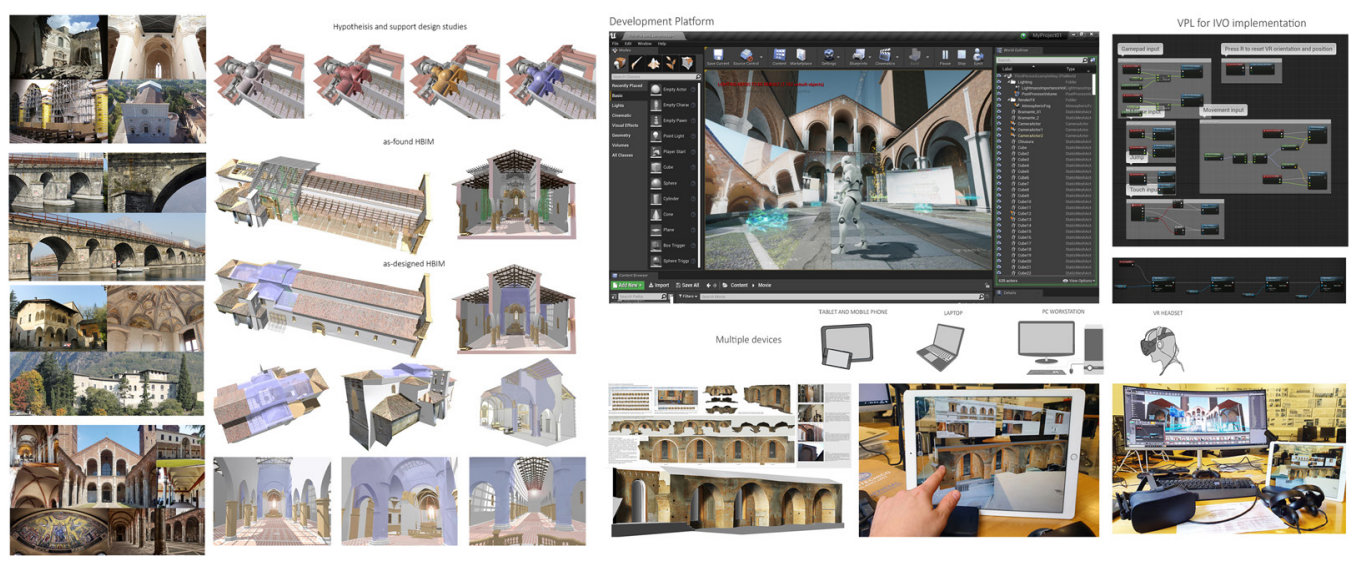


\section{Introduzione}

La ricerca scientifica nel campo della digitalizzazione del patrimonio costruito negli ultimi anni ha raccolto la sfida imposta della principali multinazionali e enti governativi orientati a supportare il ciclo di vita degli edifici attraverso tecniche e metodi sempre più all' avanguardia. In questo contesto, la rappresentazione digitale degli edifici ha beneficiato di nuovi strumenti e metodi in grado di aumentare la diffusione di informazioni legate a qualsiasi tipologie d'artefatto, passando dal processo scan-to-BIM, alla eXtended reality $(X R)$, fino intelligenza artificiale (Al). In particolare, settori disciplinari come la rappresentazione digitale 2D/3D, l'informatica, il restauro e la geomatica, seppur in modo diverso, hanno contribuito a rafforzare la transizione e la gestione digitale di manufatti storici di elevato valore storico e culturale, aumentando esponenzialmente non solo il profilo del 'metodo' ma anche quello del 'contenuto'. In questo contesto, l'osmosi creatasi tra la rappresentazione digitale e lo sviluppo informatico orientato allo creazione di nuove soluzioni digitali in grado di rispondere a loro volta alle esigenze di diverse categorie di professionisti come architetti, ingegneri, archeologi e restauratori, è risultato determinante per aumentare l' utilità dei modelli digitali per differenti tipologie d'analisi. In questo nuovo scenario, caratterizzato da profonde mutazioni economico-sociali e tecnologiche all' avanguardia, è risultato determinante comprendere e poi applicare le potenzialità di un 'fil rouge' costituitosi tra la rappresentazione digitale, l'informatica, la geomatica e il restauro a supporto del patrimonio costruito. Per questi motivi, il contributo raccoglie le esperienze dirette effettuate negli ultimi nel campo della digitalizzazione del patrimonio costruito, dimostrando come sviluppi tecnologici e metodi di ultima generazione possono supportare il ciclo di vita dell'edificio aumentando l'utilità dei modelli e la loro capacita' di interagire con l'input dell utente passando da modelli statici a modelli dinamici interattivi.

\section{La capacità di innovazione tramite la ricerca applicata nell' era del digital sharing}

Attualmente il settore delle costruzioni è testimone delle profonde mutazioni economico-sociali e tecnologiche. Questo nuovo scenario ha influenzato notevolmente la ricerca applicata nel settore edile, proponendo e sviluppando interessanti metodi e strumenti digitali in grado di supportare il ciclo di vita dell' edificio, in particolare quelli storici. Come risaputo, I' avvento del BIM e la mixed reality (VR-AR) hanno permesso ai professionisti di andare oltre semplici rappresentazioni bidimensionali, aumentando esponenzialmente il contenuto informativo di rappresentazioni digitali 3D [Carrión-Ruiz et al., 20 I9: Paladini et al., 20 19]. In particolare, il processo scan-to-BIM è stato in grado di dimostrare come trasformare semplici punti nello spazio (scansioni, nuvole di punti) in oggetti parametrici in grado di comunicare contenuti caratterizzati da differenti tipologie di informazione (meccaniche, fisiche, storiche, etc.). Di anno in anno settori disciplinari come il disegno e l'informatica hanno definito un 'fil rounge' in grado di aumentare l'utilità dei modelli per differenti tipologie d'analisi e campi d'applicazione. La figura dell' architetto ha dovuto quindi rapportarsi con un profondo cambio generazionale, dove acronimi come LOD (livello di dettaglio) e LOI (Livello di informazione) hanno caratterizzato sempre di più la rappresentazione di modelli digitali complessi e le varie normative internazionali. Alcuni interessanti studi hanno inoltre raccolto la sfida e dimostrato come bypassare la rigida architettura dei software BIM come autodesk Revit e Graphisoft Archicad non orientata alla gestione di edifici storici complessi [Banfi 2020; Brumana et al. 20 I 8; Previtali et al. 202 I ]. In questo contesto, oltre al rilievo 3D, la modellazione digitale è risultata determinante per definire nuovi requisiti scan-to-BIM, normative e best practies in grado di digitalizzare il patrimonio costruito con un elevato grado di accuratezza (GOA). LOD, LOI e soprattutto GOA sono diventati perciò fattori in grado di comunicare l'attendibilità dei modelli. In sintesi, l'avvento di nuove tecnologie dell' informazione ha permesso di spostare l' attenzione più sul 'come' fare le cose, affrontando nuove sfide imposte per la maggior parte delle volte da case sviluppatrici di software orientate alla gestione di edifici di nuova costruzione. Di conseguenza casi applicativi concreti 
orientati a supportare il processo di conservazione e restauro di edifici storici hanno dimostrato come la rappresentazione digitale può assumere diverse forme di condivisione, come il 'digital sharing', espandendo il 'contenuto' dei modelli digitali tramite 'metodi' innovativi non ancora del tutto consolidati e applicati a livello nazionale [Della Torre, 2017 ].

\section{Oltre il processo scan-to-BIM: dai modelli HBIM a nuovi livelli di interattività}

II digital shraing e la diffusione dell'open source hanno un diretto impatto sul ciclo di vita dell'edificio. Grazie a tecniche di condivisione cloud e nuovi livelli di interoperabilità dei modelli digitali è possibile creare una crescente partecipazione e condivisione tra tutti gli utenti coinvolti nel processo, definendo prospettive e approcci aperti culturalmente e spazialmente. Come si è detto e ripetuto, negli ultimi anni, il processo d' innovazione richiesto da questo scenario richiede la definizione di processi informativi innovativi e specifiche skill digitali. In questo contesto, esperti del settore delle costruzioni e informatici hanno definito nuove figure professionali e processi in grado di proporre nuova modalità digitali di condivisione dati [Tan et al. 2019]. Questo approccio olistico ha visto la rielaborazione di una grande quantità di funzioni, codici, strumenti digitali con l'obiettivo principale di aumentare l'immersività e condivisione dei modelli digitali, aumentandone il paradigma dell'interattività modello-utente. Da una punto di vista digitale il modello, nei casi studio qui riportati, è stato considerato perciò un contenitore digitale di informazioni in grado di interagire e connettere l'utente con il patrimonio costruito in diverse forme. L'utente, una volta creato il modello geometrico corrispondente a quanto rilevato dalla campagne di rilievo 3D, può arricchire il valore semantico inserendo informazioni eterogenee in grado di descrivere non solo i materiali e gli elementi architettonici impiegati ma anche il loro retaggio storico e culturale. In questo scenario la modellazione NURBS e i gradi di generazione (GOG) sono risultatati determinanti per gestire il paradigma della complessità di edifici storici complessi provenienti da rilievi 3D come la Basilica di Collemaggio dopo il terremoto del 2009, castel Masegra a Sondrio, ponte Azzone Visconti (Lecco), la basilica di Sant'Ambrogio e l'Arco della Pace (Milano) (fig. I).

L' immagine seguente mostra la comparazione dei tre principali step che portano alla realizzazione di modelli scan-to-HBIM allineati con le principali richieste e obiettivi di progetto. Tra le varie committenze, negli ultimi anni risulta necessario citare in particolar modo ENIservizi, la quale ha finanziato e supportato il restauro della Basilica di Collemaggio, premiato

Fig. I. I casi studio di ricerca: a) Basilica di b) Castello Masegra Sondrio; c) Ponte Azzone Visconti a Lecco; d) Basilica di Sant'Ambrogio Basilica di
a Milano. a)

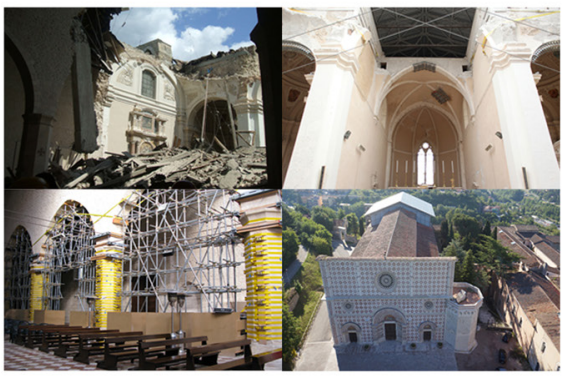

c)

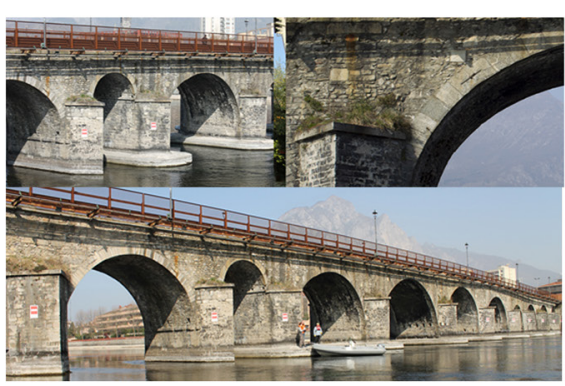

b)

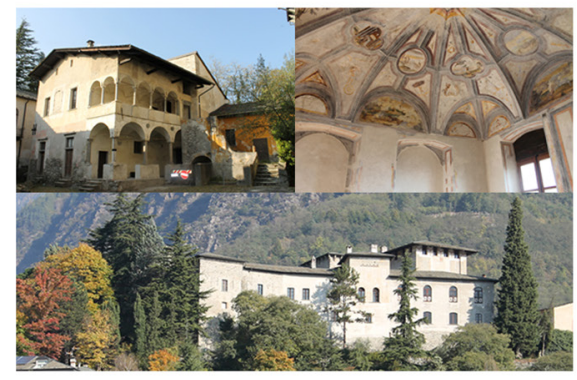

d)

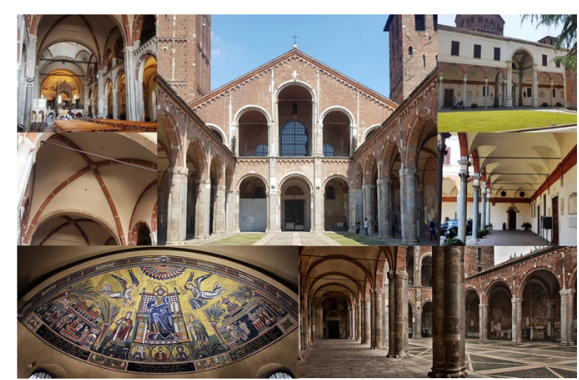


quest'ultimo con il European Heritage Award nella categoria 'Conservazione'. Come è noto, I 'intero progetto si basava su un partenariato pubblico-privato che ha coinvolto la collaborazione di tre diverse università [Brumana et al. 2018].

Grazie a questo caso applicativo, la ricerca nel campo dell'HBIM ha permesso all'autore di indagare forme di rappresentazione digitali in grado di comunicare la complessità dell' edificio a differenti discipline, dal restauro, al cantiere fino all' analisi agli elementi finiti. II programma, in particolare, ha previsto la creazione di un modello in grado di comunicare informazioni dinamiche di carattere geometrico, materico e progettuale sia per quanto riguarda lo stato di fatto sia lo stato di progetto, quest'ultimo alternatosi della classiche fasi di progetto preliminare, definitivo ed esecutivo. In questa prima fase quindi è stato possibile strutturare per fasi as-found e as-designed ed infine il progetto architettonico della basilica di Collemaggio. L'immagine in figura 2 mostra il grado di dinamicità e interattività raggiunto in una priva fase di sviluppo per la basilica di Collemagio in L'Aquila.

Successivamente, una seconda opportunità, per migliorare e condividere informazioni dinamiche tramite modelli HBIM sono stati il caso studio di Castel Masegra (Sondrio) e il Ponte Azzone Visconti (Lecco). Grazie a una profonda ricerca storica dei manufatti è stato possibile identificare soglie storiche ben delineate nel tempo per il castello e l'inserimento dei dati di livellazione e monitoraggio per l'infrastruttura medievale in modo da facilitare gli esperti coinvolti nel processo di monitoraggio all'archivio e lettura dei dati. Specifici parametri BIM sono stati sviluppati all'interno dei due progetti in modo da permettere agli utenti finali di

3D Survey data

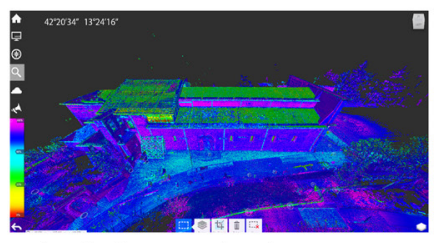

Basilica of Collemaggio in L' Aquila

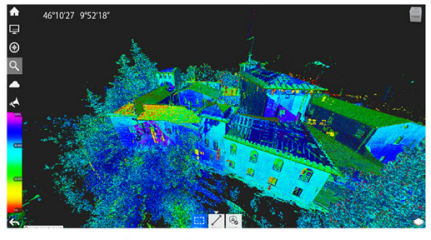

Masegra Castel in Sondrio

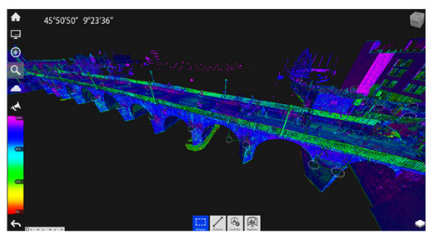

Azzone Visconti Bridge in Lecco
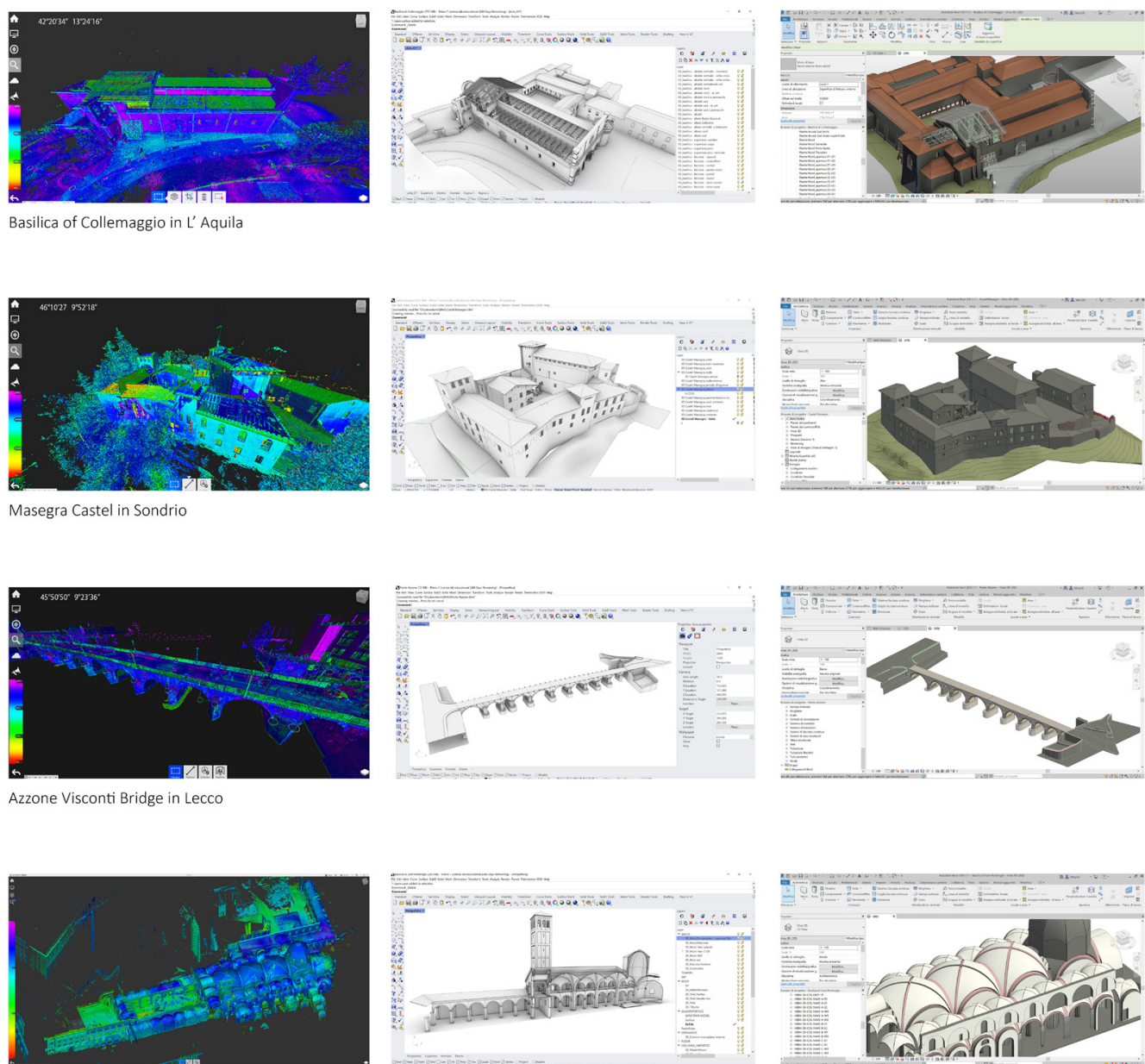

Fig. 2. II flusso di lavoro digitale applicato ai casi studio di ricerca: dal rilievo 3D ai modelli HBIM as-found.

Basilica of Sant'Ambrogio in Milan
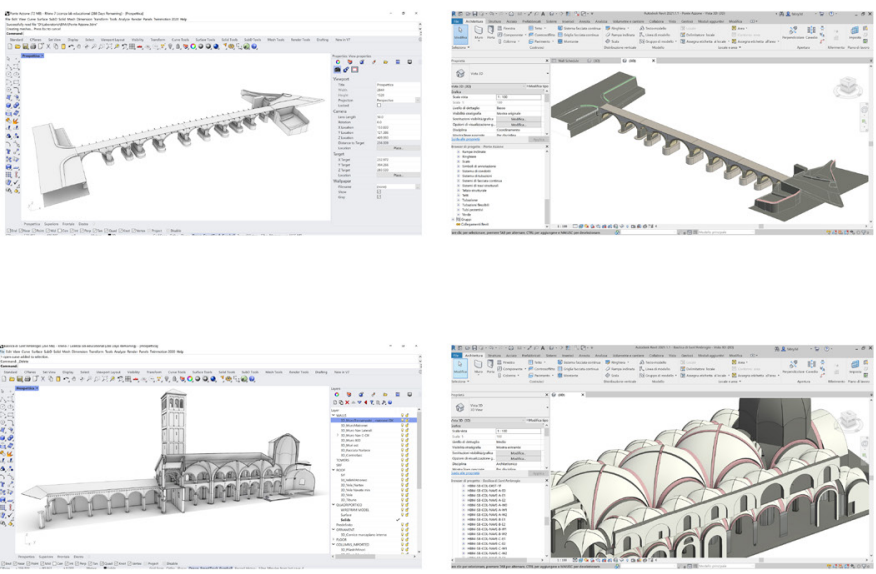
interagire dinamicamente non solo con gli elementi architettonici e strutturali dei modelli digitali ma anche con dati specifici come le fasi storiche, analisi agli elementi finiti (FEM) o i dati provenienti dal monitoraggio. Grazie allo sviluppo di nuovi parametri BIM inoltre è stato possibile collegare e richiamare data sources esterni (testi, disegni storici e risorse bibliografiche) in grado di confermare l'attendibilità delle forme geometriche realizzate nelle varie fasi storiche per castel Masegra e creare un progetto InfraBIM per l'infrastruttura medioevale in grado di condividere i dati provenienti dalla livellazione e monitoraggio [Barazzetti et al. 20 I 5; Previtali et al. 202 I]. Grazie all' identificazione di più fasi e una rappresentazione

Hypotheisis and support design studies
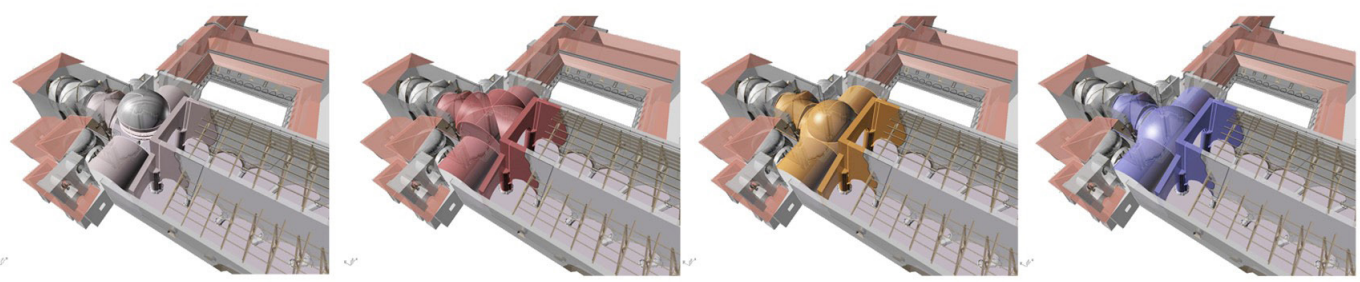

as-found HBIM
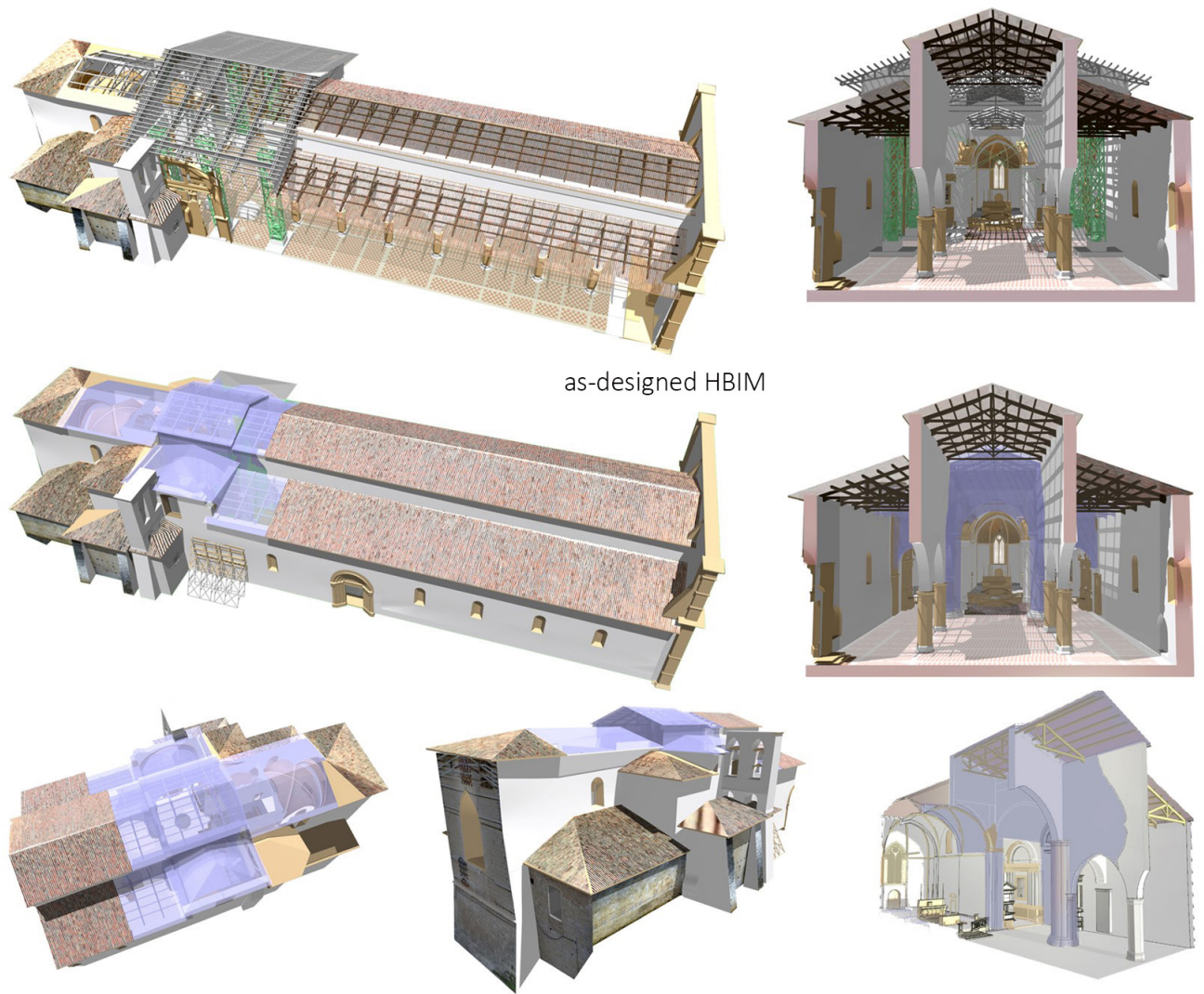

Fig. 3. II modello
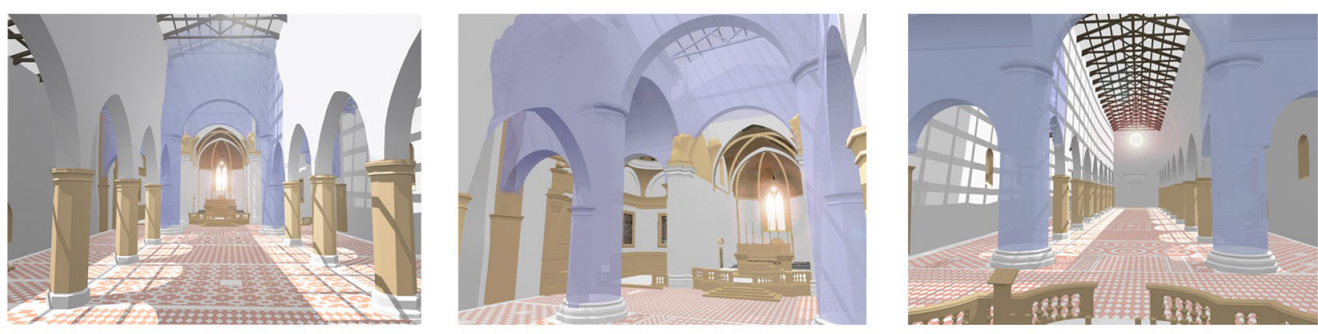
digitale che prevedeva l'applicazione di diversi livelli di dettaglio (LOD) e gradi accuratezza (GOA) è stato possibile addentrarsi quindi nello sviluppo di una visualizzazione grafico informativa dinamica. Questo ha richiesto l'identificazione di oggetti non più corrispondenti a sole partizioni murarie complete ma a suddividere quest'ultime anche in termini semantici e temporali (granular objects) [Banfi 2020] (fig. 4).

Nonostante i risultati ottenuti per quest'ultimi due casi studio, entrambi i modelli, i relativi abachi e rappresentazioni bidimensionali (piante, prospetti e sezioni) potevano essere visualizzate ed analizzati tramite la piattaforma BIM con cui sono stati sviluppati e i software BIM based utilizzati per le successive analisi. Di conseguenza, il valore informativo e l'utilità stessa dei modelli era destinato a una cerchia ristretta di esperti in grado di interagire e gestire modelli complessi con software professionali che richiedono skill avanzante. Per questo motivo, come brevemente descritto nei prossimi paragrafi, la crescente necessità di andare oltre a piattaforme BIM come Autodesk Revit e Graphisoft Archicad e facilitare l'utilizzo e lettura dei modelli informativi, ha richiesto lo sviluppo di metodi in grado di garantire a professionisti ma anche a non esperti di BIM e modellazione digitale (come studenti e turisti virtuali) una facile lettura del modelli informativi e di interagire in modo dinamico con oggetti virtuali interattivi (IVO) e piattaforme BIMcloud open (attualmente in via di sviluppo) in grado di comunicare nuove tipologie di 'contenuto'.

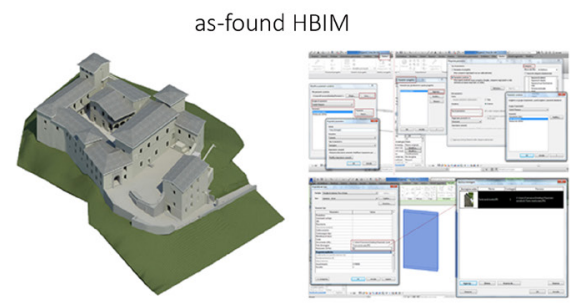

Historical phases and material-stractural analysis
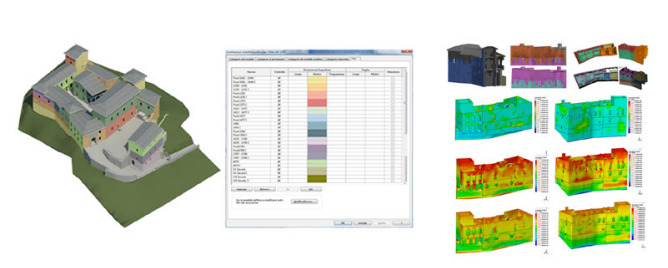

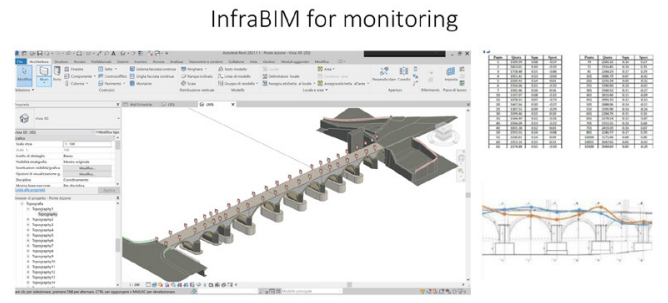

InfraBIM for AR-VR
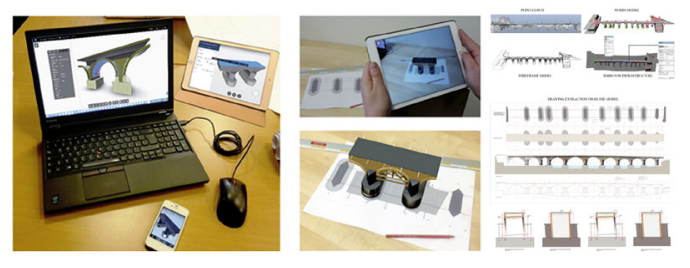

Digital sharing, modelli dinamici e oggetti virtuali interattivi (IVO) per il patrimonio costruito

Il concetto di utilità del modelli digitali, negli ultimi anni, è stato indagato di pari passo con la possibilità che i linguaggi di sviluppo informatici hanno dato principalmente ai BIM researcher, quest'últimi in grado di coniugare campi disciplinare differenti in unico progetto digitale. Come brevemente anticipato, oggi giorno è possibile sviluppare piattaforme e interfaccia grafiche grazie allo studio, analisi e rielaborazioni di specifiche APIs condivise dalla principali case produttrici di software per l'architettura. Come anticipato nel simposio REAACH, è in corso attualmente lo sviluppo di una piattaforma open BIMcloud, con l'obiettivo principale di raccogliere, archiviare e condividere una grande quantità di casi studio. In questo progetto, il livello di interattività porterà l'utente finale ad immergersi ed interagire in modo dinamico con una grande quantità di contenuti, dai classici file testuali e file multimediali a progetti $\mathrm{HBIM}$ e MR più articolati e complessi. Recentemente, una terza fase di sviluppo è stata indagata per quanto riguarda il livello di interattività modello-utente. In particolare, grazie a nuove forme open di visual scripting è stato possibile dar vita a oggetti parametri statici che fino 
ad oggi ero considerati solo dei contenitori di informazioni. Come risaputo, negli ultimi anni, piattaforme di sviluppo di videogiochi sono state impiegate nel campo delle costruzioni per aumentare la condivisione digitale di progetti architettonici. Allo stesso tempo piattaforme come Unity, Blender, Unreal Engine e TwinMotion hanno permesso in una logica completamente open di poter sviluppare attraverso nuovi comandi e linguaggi di programmazione mondi digitali in grado di interagire con l'utente attraverso differenti tipologie di dispositivi: dal mobile phone e tablet fino agli headsedt VR di ultima generazione come l'Oculus Guest (fig. 5). II caso di studio della Basilica di Sant'Ambrogio e' stato orientato al racconto virtuale del loro background storico, culturale e artistico. L' immagine seguente mostra il metodo applicato che ha permesso la conversione di una grande quantità di oggetti statici in IVOs per raccontare per il caso studio della Basilica le sue vicissitudine storiche culturali, il suo incredibile apparato decorativo e i restauri succedutesi nel tempo. L' immagine 5 mostra il valore aggiunto di metodi consolidati in grado di trasferire la ricchezza informativa e geometrica dei modelli scan-to-BIM in ambienti immersivi caratterizzati a loro volta da oggetti virtual interattivi (IVO) in grado di comunicare diverse tipologie di informazioni in base agli input dell'utente.

\section{Conclusioni}

La velocità di cambiamento di forme digitali in grado di concretizzare la ricchezza incluse in progetti BIM per edifici di elevato valore storico e culturale (HBIM), recentemente è stata supportata dalla condivisione di liberie di APIs come Autodesk Forge, Revit API, e piattaforme di sviluppo come Unreal Engine, Twinmotion e Unity. Questa contributo, riporta in modo critico gli sviluppi e risultati ottenuti nel processo di digitalizzazione del patrimonio costruito, analizzando pro e contro delle soluzioni proposte in vista della nuova norma UNI I 337 che delineerà metodi e contenuti nei prossimi anni nel panorama nazionale. Dall'altra parte, i casi studio qui riportati presentano un progressivo aumento dei livelli di interattivita' tra utente-modello e contenuti collegati a supporto di realta' storico-sociali-culturali. L'applicazione di un processo scan-to-BIM e la successiva implementazione informatica ha posto le basi per poter rispondere in modo omnicomprensivo alle esigenze europee orientate
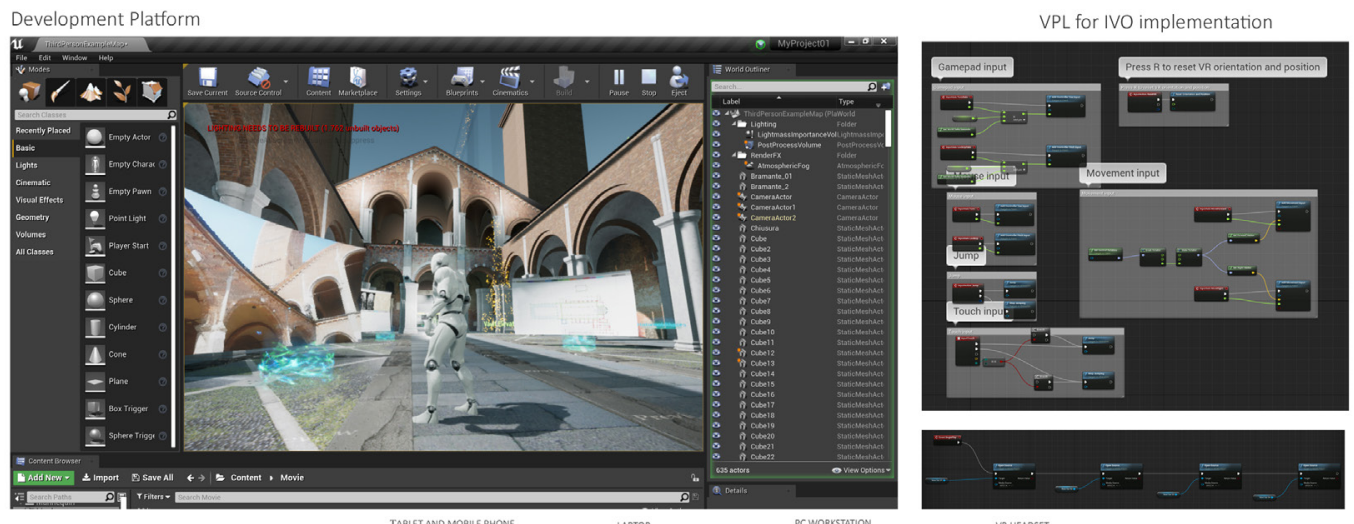

Multiple devices
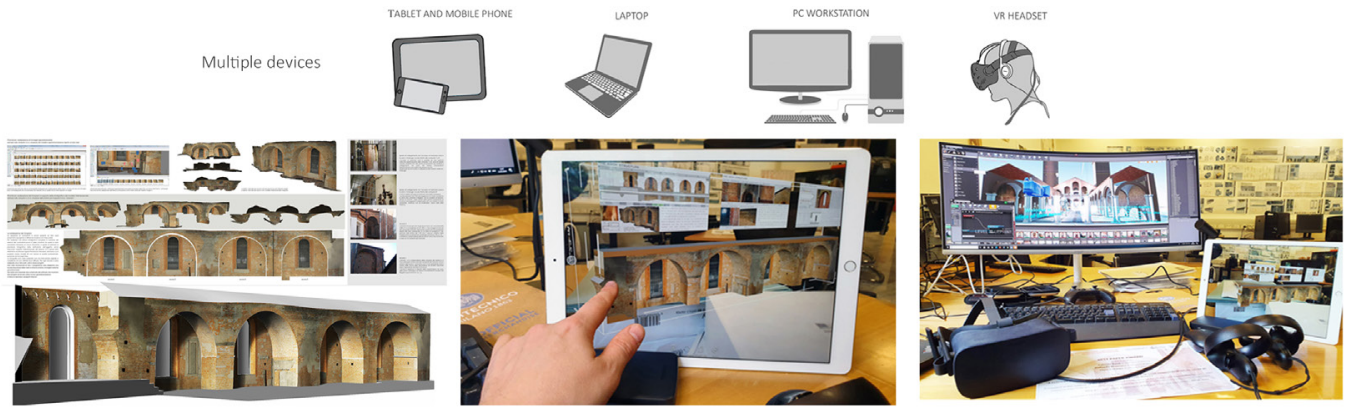
ad estendere l'utilita' dei modelli digitali al patrimonio costruito e alla digitalizzazione dei musei e delle loro collezioni. Per questi motivi, l' attenzione è posta soprattutto su come modelli digitali possano prendere vita grazie all' interazione utente-modello, passando da rappresentazioni 3D statiche a modelli dinamici e oggetti virtual interattivi (IVO) in grado di condividere diverse tipologie di informazione e file multimediali a favore di nuove forme di digital sharing ed eXtended reality $(X R)$.

\section{Riferimenti bibliografici}

Banfi F. (2020). HBIM, 3D drawing and virtual reality for archaeological sites and ancient ruins. In Virtual Archaeology Review, II (23), pp. I6-33.

Barazzetti L., Banfi F., Brumana R., Gusmeroli G., Previtali M., Schiantarelli G. (20 I 5). Cloud-to-BIM-to-FEM: Structural simulation with accurate historic BIM from laser scans. In Simulation Modelling Practice and Theory, 57, pp. 7I-87.

Brumana R., Della Torre S., Previtali M., Barazzetti L., Cantini L., Oreni D., Banfi F. (20 I 8). Generative HBIM modelling to embody complexity (LOD, LOG, LOA, LOI): surveying, preservation, site intervention - the Basilica di Collemaggio (L'Aquila). In Applied geomatics, IO(4), pp. 545-567.

Carrión-Ruiz B., Blanco-Pons,S., Weigert A., Fai S., Lerma J. L. (2019). Merging photogrammetry and augmented reality: The Canadian Library of Parliament. In International Archives of the Photogrammetry, Remote Sensing and Spatial Information Sciences, 42(2MI I), pp. 367-37I.

Della Torre S. (2017). Un bilancio del progetto BHIMM. In Modellazione e gestione delle informazioni per il patrimonio edilizio esistente (pp. 10-16). Ingenio.

Paladini A., Dhanda A., Reina Ortiz M., Weigert A., Nofal E., Min A., Santana Quintero M. (2019). Impact of virtual reality experience on accessibility of cultural heritage. In The International Archives of the Photogrammetry, Remote Sensing and Spatial Information Sciences, $42(2 \mathrm{WI}$ I), pp. 929-936.

Previtali M., Brumana R., Banfi F. (2020). Existing infrastructure cost effective informative modelling with multisource sensed data:TLS, MMS and photogrammetry. In Applied Geomatics, I-20.

Tan S., Yang Y., Leopold C., Robeller C., \& Weber U. (2019). Augmented Reality and Virtual Reality: New Tools for Architectural Visualization and Design. In Research Culture in Architecture, pp. 30 I-3 I 0. Basilea: Birkhäuser.

Wong J., Wang X., Li H., Chan G. (20I4). A review of cloud-based BIM technology in the construction sector. In Journal of information technology in construction, 19, pp. 28I-291.

\section{Autore}

Fabrizio Banfi, Politecnico di Milano, fabrizio.banfi@polimi.it

Per citare questo capitolo: Banfi Fabrizio (2021). Modelli dinamici interattivi per il patrimonio costuito/Dynamic Interactive Models for Built Heritage. In Arena A. Arena M. Mediati D. Raffa P. (a cura di). Connettere. Un disegno per annodare e tessere Linguagoi Distanze Tecnologie Atti del $42^{\circ}$ Convegno Internazionale dei Docenti delle Discipline della Rappresentazione/Connecting. Drawing for weaving relationship. Languages Distances Technologies. Proceedings of the 42th International Conference of Representation Disciplines Teachers. Milano: FrancoAngeli, pp. 1998-2013. 


\title{
Dynamic Interactive Models for Built Heritage
}

\author{
Fabrizio Banfi
}

\section{Abstract}

In the last few years, innovative methods able to improve the digitization process of heritage buildings based on a scan-to-BIM process, have brought countless benefits in different disciplinary fields oriented to the management of the built heritage. On the other hand, the scan-to-BIM process still involves static forms and low levels of interactivity between the user and digital models. For this reason, in recent years, the author's research has focused on increasing the utility and interactivity paradigms of digital models with the aim of improving the transmissibility of the tangible and intangible values of our built heritage through the implementation of the latest generation tools and techniques in the field of HBIM, Digital Twin and Extended Reality (XR).

Keywords

scan-to-BIM, built heritage, eXtended reality, interactivity, technologies, digital-sharing.

The digital models based on a scan-toBIM process and the levels of interactivity levels of interactivity obtained through the latest generation $X \mathrm{R}$
techniques and devices.
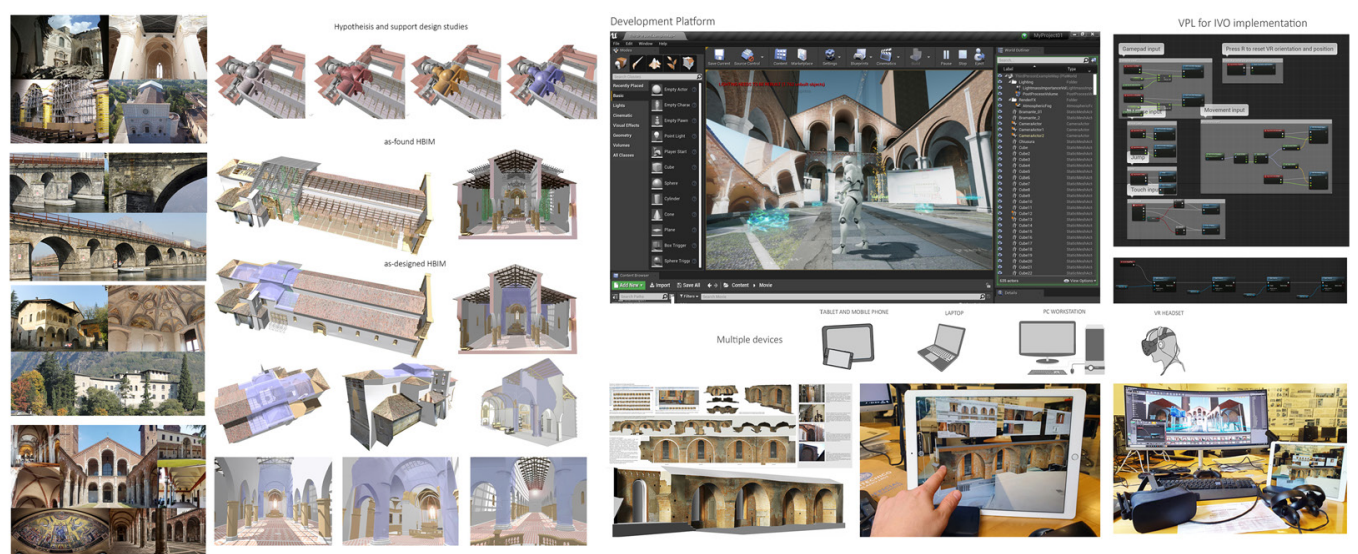


\section{Introduction}

In recent years, scientific research in the field of digitization of built heritage has taken up the challenge imposed by the major multinationals and governmental bodies aimed at supporting the life cycle of buildings through increasingly advanced techniques and methods. In this context, the digital representation of buildings has benefited from new tools and methods capable of increasing the dissemination of information related to any type of artefact, passing from the scan-to-BIM process, to eXtended reality $(X R)$, up to artificial intelligence (AI). In particular, disciplinary sectors such as 2D / 3D digital representation, computer science, preservation, restoration and geomatics have contributed to strengthening the transition and digital management of historical artefacts of high historical and cultural value, increasing exponentially not only the profile of the 'method' but also that of the 'content'. In this context, the osmosis created between digital representation and IT development oriented towards the creation of new digital solutions capable of responding in turn to the needs of different categories of professionals such as architects, engineers, archaeologists and restorers, has proved decisive for increase the usefulness of digital models for different types of analysis. In this new scenario, characterized by profound economic-social and technological changes at the cutting edge, it was crucial to understand and then apply the potential of a 'fil rouge' constituted between digital representation, information technology, geomatics and supporting the preservation of built heritage. For those reasons, the contribution collects the direct experiences made in recent years in the field of digitization of built heritage, demonstrating how technological developments and latest generation methods can support the life cycle of the building by increasing the usefulness of the models and their capacity to interact with user-input by passing from static models to interactive dynamic models.

\section{The ability to innovate through applied research in the era of digital sharing}

Currently, the construction sector is witnessing profound economic, social and technological changes. This new scenario has greatly influenced applied research in the construction sector, proposing and developing interesting methods and digital tools capable of supporting the life cycle of the building. As is well known, the advent of BIM and mixed reality (VR-AR) have allowed professionals to go beyond simple two-dimensional representations, exponentially increasing the information content of 3D digital representations [Carrión-Ruiz et al. 2019: Paladini et al. 2019]. In particular, the scan-to-BIM process was able to demonstrate how to transform simple points in space (scans, point clouds) into parametric objects capable of communicating contents characterized by different types of information (mechanical, physical, historical, etc.). From year to year disciplinary sectors such as design and information technology have defined a 'fil rouge' capable of increasing the usefulness of the models for different types of analysis and fields of application. The figure of the architect, therefore, had to deal with a profound generational change, where acronyms such as LOD (level of detail) and LOI (level of information) have increasingly characterized the representation of complex digital models and various international standards. Some interesting studies have also taken up the challenge and demonstrated how to bypass the rigid architecture of BIM software such as Autodesk Revit and Graphisoft Archicad not oriented to the management of complex historical buildings [Banfi 2020, Brumana et al.,20 I 8; Previtali et al., 202 I ]. In this context, in addition to 3D surveying, digital modelling has proved crucial to define new scan-to-BIM requirements, regulations and best practices capable of digitizing the built heritage with a high grade of accuracy (GOA). LOD, LOI and above all GOA have therefore become factors capable of communicating the reliability of the models. In summary, the advent of new information technologies has made it possible to shift the focus more on 'how' to do things, facing new challenges imposed for the most part by software developers oriented to the management of new buildings. Consequently, innovative research case studies aimed at supporting the conser- 
vation and restoration process of historic buildings have shown how digital representation can take different forms of sharing, such as 'digital sharing', expanding the 'content' of digital models through innovative 'methods' not yet fully consolidated and applied at the national level [Della Torre 2017].

\section{Beyond the scan-to-BIM process: from HBIM models to new levels of interactivity}

Digital sharing and the spread of open source have a direct impact on the life cycle of the building. Thanks to cloud sharing techniques and new levels of interoperability of digital models, it is possible to create growing participation and sharing among all the users involved in the process, defining culturally and spatially open perspectives and approaches. As has been said and repeated, in recent years, the innovation process has required the definition of innovative information processes and specific digital skills. In this context, experts in the construction and IT sectors have defined new professional figures and digital workflows capable of proposing new digital methods of data sharing. This holistic approach has seen the reworking of a large number of functions, codes, digital tools with the main objective of increasing the immersion and sharing of digital models, increasing the model-user interactivity paradigm [Tan et al. 2019]. From a digital point of view, the model was therefore considered a digital container of information capable of interacting and connecting the user with the heritage built in different forms. Once the user has created the geometric model corresponding to what was detected by the 3D survey campaigns, he can enrich the semantic value by inserting heterogeneous information capable of describing not only the materials and architectural elements used but also their historical and cultural heritage. In this scenario, NURBS modelling and grade of generation (GOG) were found to be decisive for managing the paradigm of the complexity of historical buildings from 3D surveys such as the Basilica of Collemaggio after the 2009 earthquake, Masegra castle in Sondrio, Azzone Visconti bridge (Lecco) and the basilica of Sant'Ambrogio (Milan) (fig. I).

The following figure shows the comparison of the three main steps that lead to the creation of scan-to-HBIM models aligned with the main project requirements and objectives (fig. 2). Among the various commissions, in recent years it is necessary to mention in particular ENIservizi, which financed and supported the restoration of the Basilica of Collemaggio, which was awarded the latter with the European Heritage Award in the 'Conservation'

a)

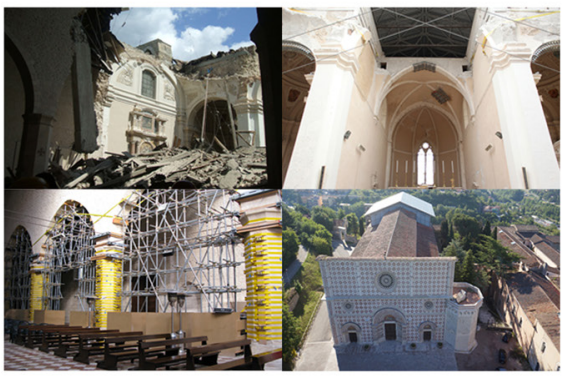

c)

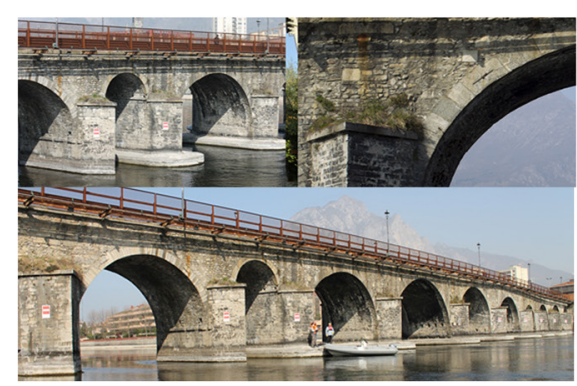

b)

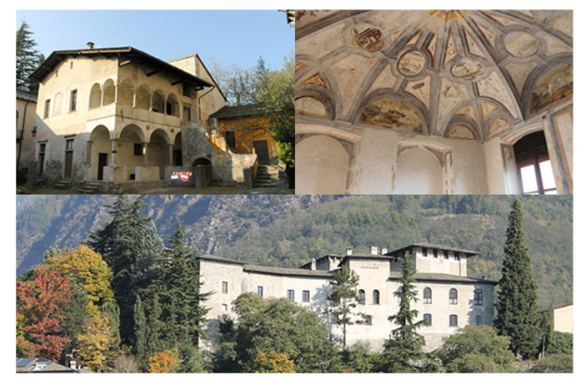

d)

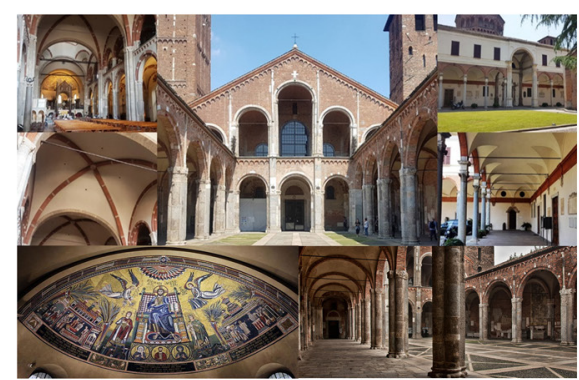


category. The entire project was based on a public-private partnership that involved the collaboration of three different universities [Brumana et al. 20 I 8].

Thanks to this research case study, research in the field of HBIM has allowed the author to investigate forms of digital representation capable of communicating the complexity of the heritage building to different disciplines, from restoration, preservation to construction site up to finite element analysis (FEA). The project, in particular, envisaged the creation of a model capable of communicating dynamic information of a geometric, material and design nature both in terms of the state of the project, the latter alternating with the classic preliminary, final and executive design phases. Figure 3 shows the level of dynamism and interactivity achieved in a phase of development for the basilica di Collemaggio (L'Aquila). Subsequently, a second opportunity to improve and share dynamic information through HBIM models was the case study of Castel Masegra (Sondrio) and Ponte Azzone Visconti (Lecco). Thanks to deep historical research of the artefacts it was possible to identify well-defined historical phases and create specific BIM parameters within the two projects to allow end-users to interact dynamically not only with the architectural and structural elements of the digital models but also with specific data such as historical phases, finite element analysis (FEM), data monitoring and mixed reality (VR-AR) [Barazzetti et al. 20 I5; Prevtiali et al. 202 I].

Thanks to the identification of several phases and a digital representation that involved the application of different levels of detail (LOD) and grade of accuracy (GOA), it was

3D Survey data

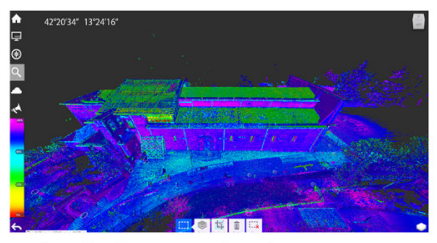

Basilica of Collemaggio in L' Aquila

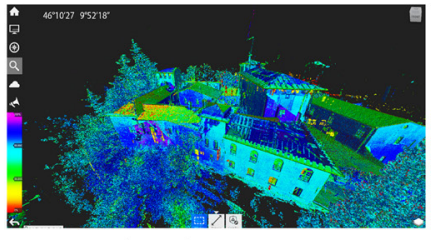

Masegra Castel in Sondrio

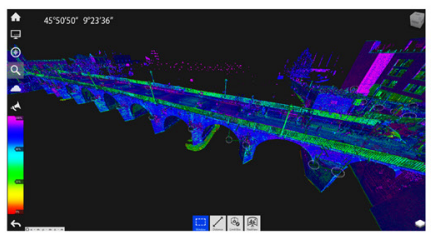

Azzone Visconti Bridge in Lecco
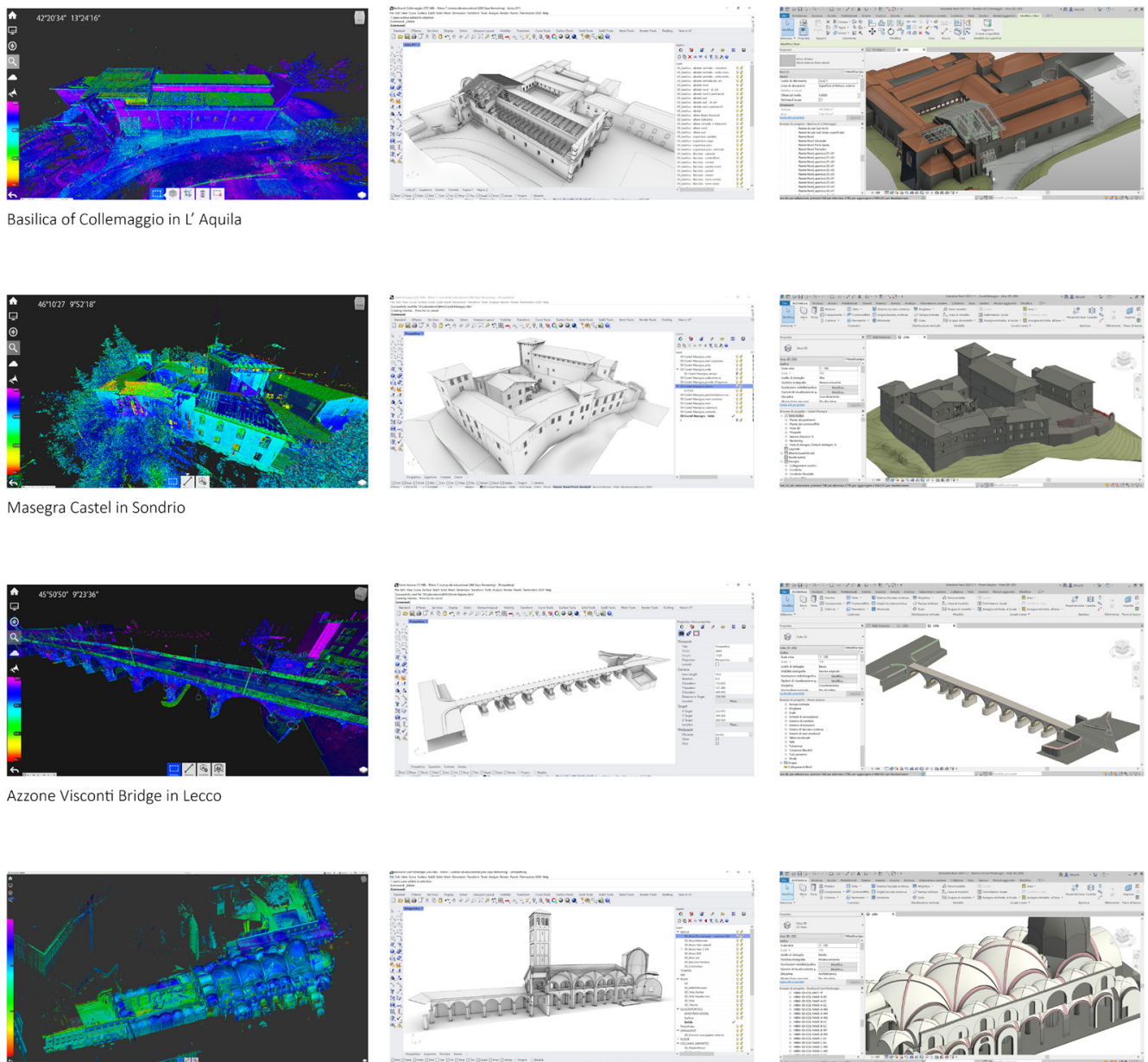

Fig. 2. The digital workflow applied to the research case studies: from 3D survey to HBIM as-found models.
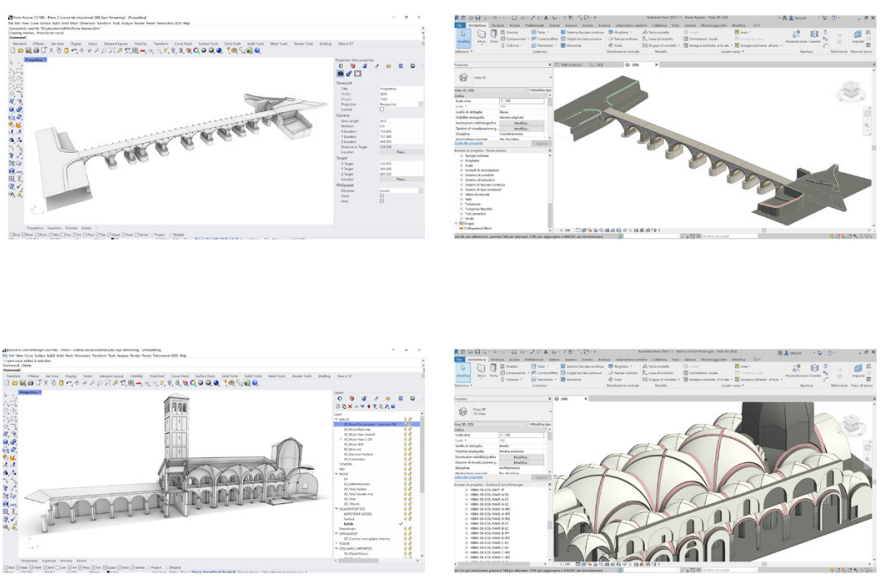
then possible to go into the development of a dynamic graphic information display. This required the identification of objects no longer corresponding only to complete wall partitions but to subdivide the latter also in semantic and temporal terms (granular objects) [Banfi 2020](fig. 4).

Despite the results obtained for the latter two case studies, both models, the related abacuses and two-dimensional representations (plans, elevations and sections) could be viewed and analyzed through the BIM platform with which they were developed and the BIM-based software used for the subsequent analyses. Consequently, the informative

Hypotheisis and support design studies
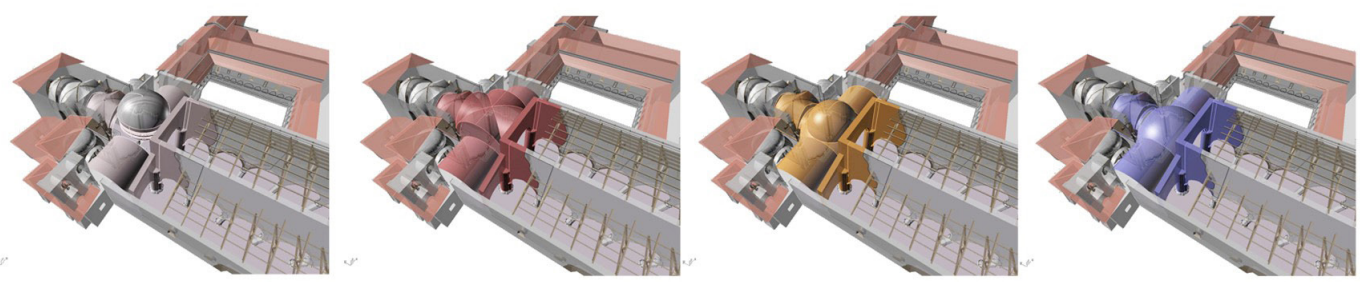

as-found HBIM
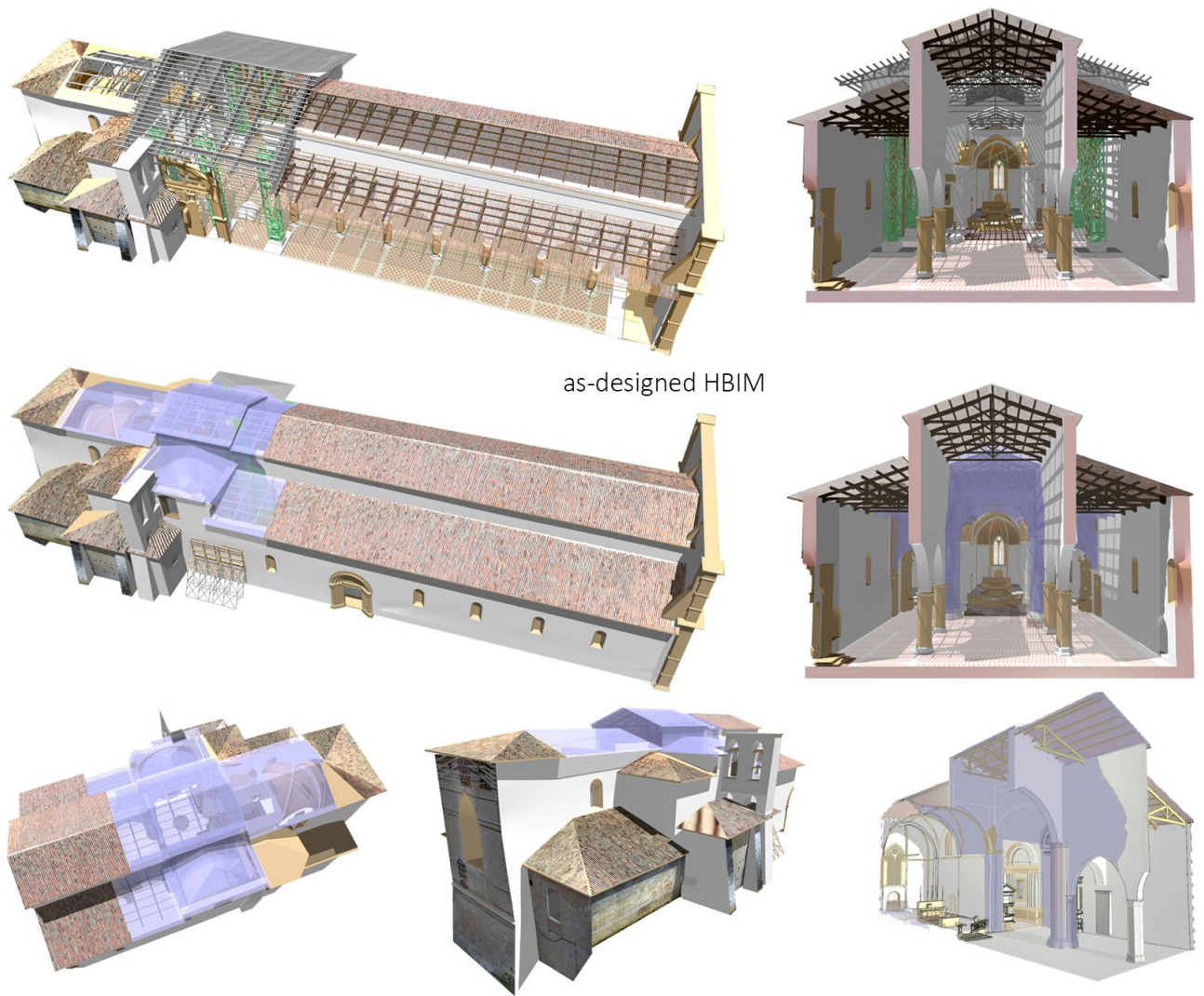

Fig. 3.The HBIM model of the Basilica di Collemaggio and its dynamic configurations for the restoration project.
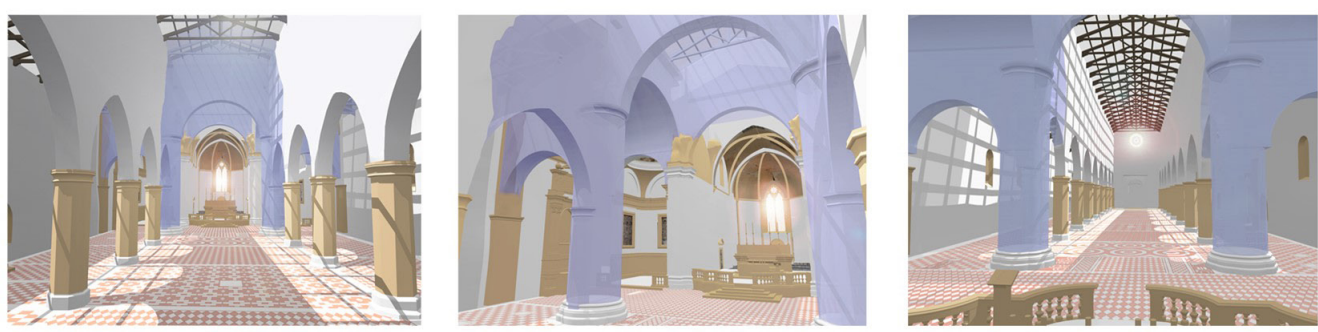
value and the very usefulness of the models were intended for a small circle of experts able to interact and manage complex models with professional software that require advanced skills.

For those reasons, as briefly described in the next paragraphs, the growing need to go beyond BIM platforms such as Autodesk Revit and Graphisoft Archicad and facilitate the use and reading of BIM models, has required the development of methods capable of guaranteeing professionals but also for non-BIM and digital modelling experts (such as students and virtual tourists) an easy reading of the information models and to interact dynamically with interactive virtual objects (IVO) and open BIMcloud platforms (currently under development) capable of communicating new types of 'content'.

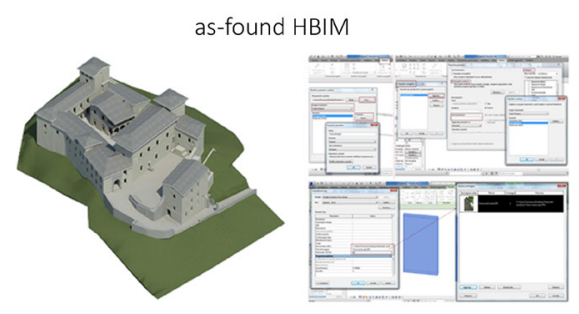

Historical phases and material-stractural analysis
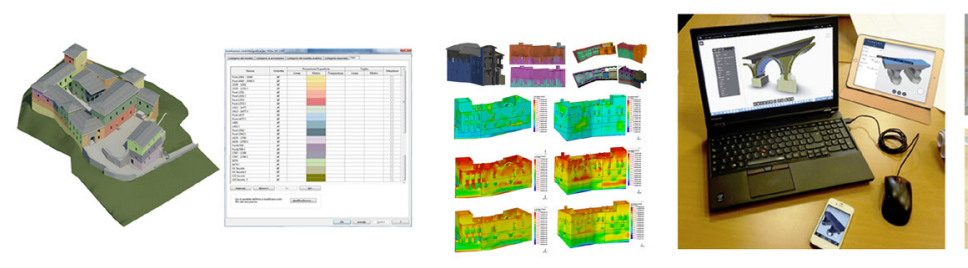

fraBIM for AR-VR
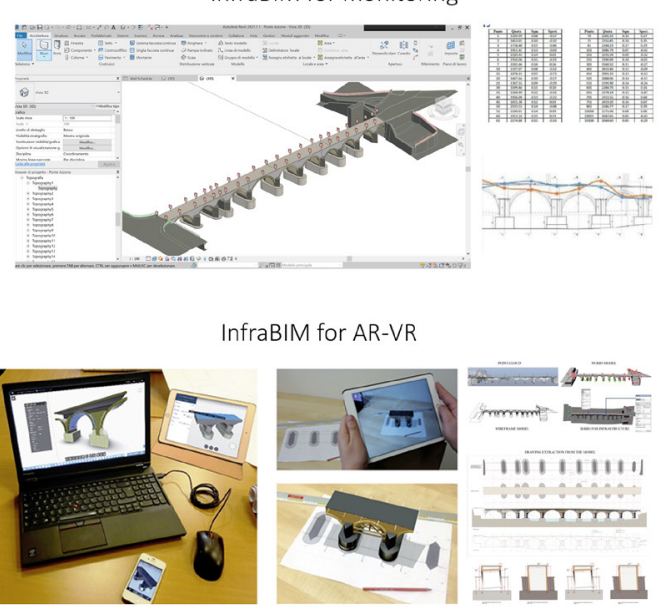

\section{Digital sharing, dynamic models and interactive virtual objects (IVO) for built heritage}

As briefly anticipated, nowadays it is possible to develop graphical platforms and interfaces thanks to the study, analysis and reworking of specific APIs shared by the main architecture software manufacturers. The development of an open cloud-based BIM platform is currently underway, with the main objective of collecting, storing and sharing a large number of case studies [Wong et al. 2014]. In this project, the level of interactivity will lead the end-user to immerse themselves and interact dynamically with a large amount of content, from classic text files and multimedia files to more complex HBIM and MR projects. On the other hand, recently, the third phase of development has been investigated as regards the level of user-model interactivity.Video game development platforms have been employed in the construction sector to increase the digital sharing of architectural projects. At the same time, platforms such as Unity, Blender, Unreal Engine and TwinMotion have allowed a completely open logic to be able to develop digital worlds capable of interacting with the user through different types of devices: from the mobile phone and tablets up to the latest generation headset VR such as the Oculus Guest. For this last phase of development, the case study of the Basilica of Sant'Ambrogio was oriented towards the virtual-visual storytelling of their historical, cultural and artistic background. The following figure shows the applied method that allowed the conversion of a large number of static objects into IVOs. In particular, the transformation from static models to IVOs was supported by the visual programming language (VPL) known as BluePrint. It is any node-based VPL that lets users create programs by manipulating program elements graphically rather than by specifying them textually. Figure 5 shows 
the added value of consolidated methods capable of transferring the informative and geometric richness of the scan-to-BIM models in immersive environments characterized in turn by interactive virtual objects able to communicate different types of information based on user inputs.

\section{Conclusion}

This paper critically reports the developments and results obtained in the digitalization process of the built heritage, analyzing the pros and cons of the solutions proposed given the new UNI I I 337 standard which will outline methods and contents in the coming years in the national panorama. On the other hand, the case studies reported show a progressive increase in the levels of interactivity between user-model and related content in support of historical-social-cultural realities. The application of a scan-to-BIM process and the subsequent IT implementation laid the foundations to be able to respond comprehensively to the European needs aimed at extending the usefulness of digital models to the built heritage and the digitization of museums and their collections. For those reasons, the focus is mainly on 'how' digital models can come to life thanks to user-model interaction, passing from static $3 \mathrm{D}$ representations to dynamic models and interactive virtual objects (IVO) able to share different types of information and multimedia outputs in favour of new forms of digital sharing and eXtended reality $(X R)$.
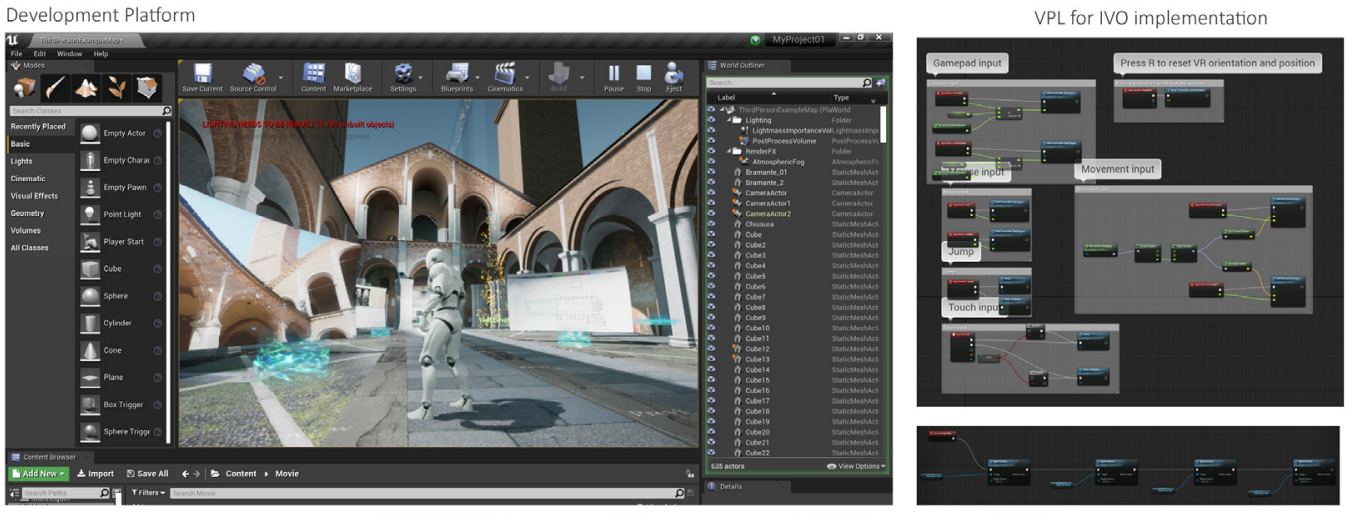

Fig. 5. The fourth phase of development based on visual programming language (VPL): from static models to

interactive digital objects (IVO).

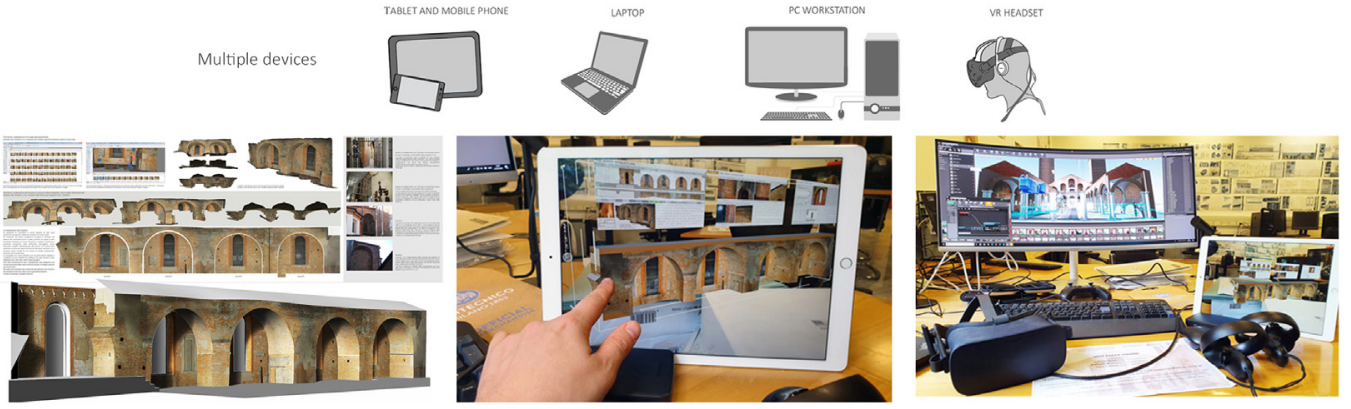

\section{References}

Banfi F. (2020). HBIM, 3D drawing and virtual reality for archaeological sites and ancient ruins. In Virtual Archaeology Review, I I (23), pp. I6-33.

Barazzetti L., Banfi F., Brumana R., Gusmeroli G., Previtali M., Schiantarelli G. (20 I 5). Cloud-to-BIM-to-FEM: Structural simulation with accurate historic BIM from laser scans. In Simulation Modelling Practice and Theory, 57, pp. 7I-87.

Brumana R., Della Torre S., Previtali M., Barazzetti L., Cantini L., Oreni D., Banfi F. (20 I 8). Generative HBIM modelling to embody complexity (LOD, LOG, LOA, LOI): surveying, preservation, site intervention - the Basilica di Collemaggio (L'Aquila). In Applied geomatics, $10(4)$, pp. 545-567. 
Carrión-Ruiz B., Blanco-Pons,S., Weigert A., Fai S., Lerma J. L. (2019). Merging photogrammetry and augmented reality: The Canadian Library of Parliament. In International Archives of the Photogrammetry, Remote Sensing and Spatial Information Sciences, 42(2MII), pp. 367-37I.

Della Torre S. (2017). Un bilancio del progetto BHIMM. In Modellazione e gestione delle informazioni per il patrimonio edilizio esistente (pp. 10-16). Ingenio.

Paladini A., Dhanda A., Reina Ortiz M., Weigert A., Nofal E., Min A., Santana Quintero M. (2019). Impact of virtual reality experience on accessibility of cultural heritage. In The International Archives of the Photogrammetry, Remote Sensing and Spatial Information Sciences, 42(2MI I), pp. 929-936.

Previtali M., Brumana R., Banfi F. (2020). Existing infrastructure cost effective informative modelling with multisource sensed data:TLS, MMS and photogrammetry. In Applied Geomatics, I-20.

Tan S., Yang Y., Leopold C., Robeller C., \& Weber U. (2019). Augmented Reality and Virtual Reality: New Tools for Architectural Visualization and Design. In Research Culture in Architecture, pp. 301 -3 I O. Basilea: Birkhäuser.

Wong J., Wang X., Li H., Chan G. (20I4). A review of cloud-based BIM technology in the construction sector. In Journal of information technology in construction, 19, pp. 28I-29I.

\section{Author}

Fabrizio Banfi, Politecnico di Milano, fabrizio.banfi@polimi.it

To cite this chapter. Banfi Fabrizio (2021). Modelli dinamici interattivi per il patrimonio costuito/Dynamic Interactive Models for Built Heritage. In Arena A., Arena M., Mediati D., Raffa P. (a cura di). Connettere. Un disegno per annodare e tessere. Linguaggi Distanze Tecnologie. Atti del $42^{\circ}$ Convegno Internazionale dei Docenti delle Discipline della Rappresentazione/Connecting. Drawing for weaving relationship. Languages Distances Technologies. Proceedings of the 42th International Conference of Representation Disciplines Teachers. Milano: FrancoAngeli, pp. 1998-20I3. 